\title{
Effect of cholecystectomy on the role of the gall bladder in fat absorption
}

\author{
A. KRONDL, H. VAV̌̌INKOVÁ, AND Č. MICHALEC \\ From the Institute of Human Nutrition, Prague, and the \\ Laboratory for Proteosynthesis, Charles University, Prague
}

EDITORIAL SYNOPSIS These studies show that gall bladder function is not necessary for the normal absorption of butter fat and olive oil. Other mechanisms are necessary to explain fat intolerance after cholecystectomy.

It is generally agreed that evacuation of the gall bladder enhances the digestion and absorption of fat. Clinical experience or phylogenetic considerations (Ivy, 1953; Schöndube, 1955) are quoted in support of this opinion. Unfortunately convincing evidence is lacking. Some studies performed after cholecystectomy in man (Bučko and Dvorský, 1957; Fedor and Fisher, 1960), in the dog (Heersma and Annegers, 1948), and in the cat (Ginter, Bobek, Blažek, and Cerveň, 1963) indicate that the gall bladder may play a minor role in fat absorption.

The rising incidence of biliary disease and of cholecystectomy stimulated us to a detailed study of this problem. The digestion (Krondl, 1961a, b) and absorption (Krondl, 1961c, d, e) of fat were compared in patients after cholecystectomy and in control subjects.

\section{METHODS AND RESULTS}

Experiments 1 and 2 were performed in patients after cholecystectomy. There was no evidence of hepatic, pancreatic, or small bowel disease, nor was there any defect of intermediary fat metabolism.

EXPERIMENT 1 Eight control subjects and eight patients who had undergone cholecystectomy (mean age 42 years for both) were given $180 \mathrm{~g}$. of cream ( $33 \%$ of fat; mean fat dose $0.85 \mathrm{~g} . / \mathrm{kg}$. body weight). The serum level of esterified fatty acids was estimated (Stern and Shapiro, 1953) while the subjects were fasting and two, three, four, and six hours following the fat meal.

No significant differences in alimentary lipaemia between patients after cholecystectomy and controls were observed (Fig. 1). In both groups the course of individual curves revealed a distinct variability.

EXPERIMENT 2 In the next experiment the fat was given intraduodenally to exclude the influence of gastric emptying on fat absorption. Olive oil, $50 \mathrm{ml}$., was given by means of an Einhorn tube over 30 minutes to 10 control subjects (mean age 42.2 years) and to 10 patients after cholecystectomy (mean age $43 \cdot 1$ years). The mean fat dose was $0.86 \mathrm{~g} . / \mathrm{kg}$. body weight. During the four hours following the fat meal samples were withdrawn and the concentration of total bile acids was estimated (Cottet, 1939) as a measure of gall bladder evacuation. The serum esterified fatty acid level was measured as before.

The administration of oil caused a marked increase of intestinal bile acid concentration in

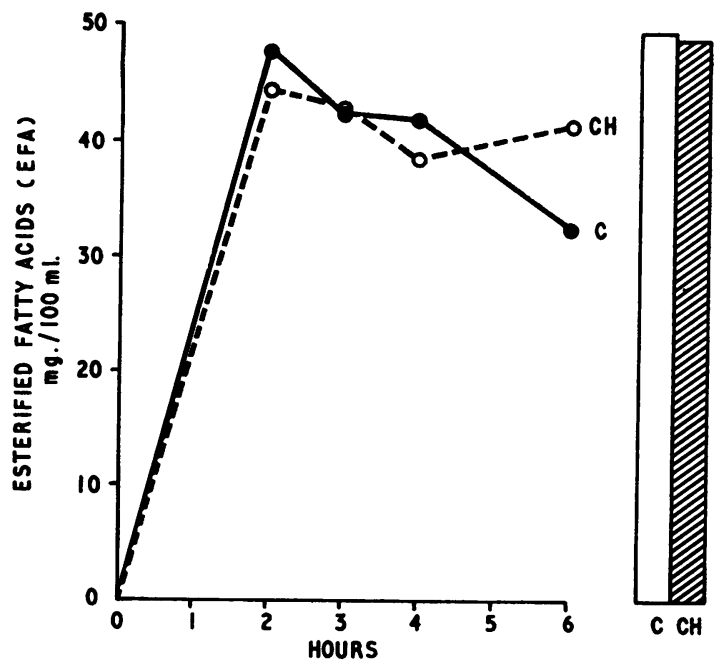

FIG. 1. The absorption of fat after ingestion of $180 \mathrm{~g}$. of whipped cream (fat $0.85 \mathrm{~g} . / \mathrm{kg}$. body weight). Full line is mean curve of esterified fatty acid in eight controls $(C)$, and broken line mean curve in eight patients $(\mathrm{CH})$ after cholecystectomy. Columns denote areas of mean curves in controls and after cholecystectomy. 

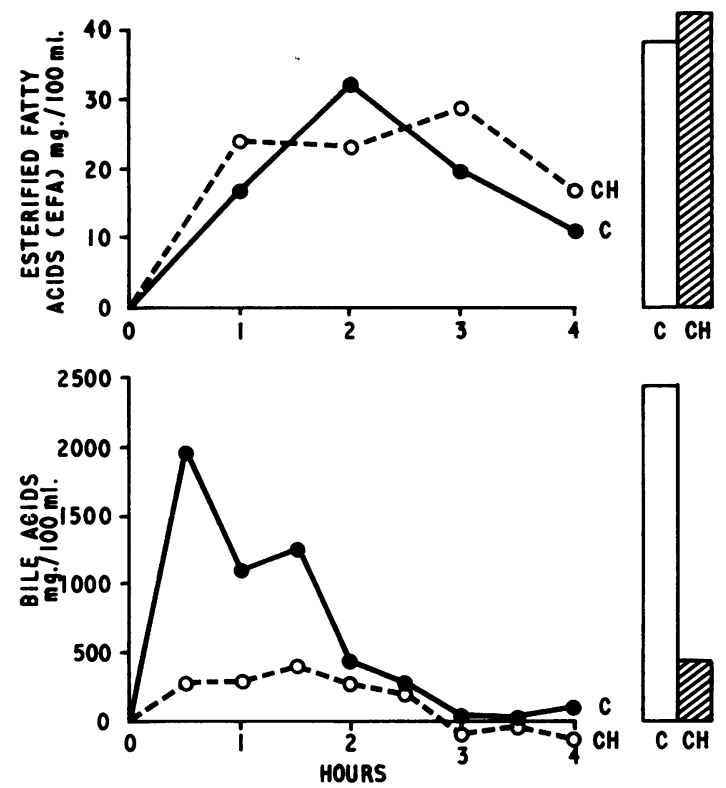

FIG. 2. The absorption of fat and intestinal total bile acid concentration after intraduodenal administration of $50 \mathrm{ml}$. olive oil ( $(0.86 \mathrm{~g}$. fat body weight) in 10 controls $(C)$ and 10 patients $(\mathrm{CH})$ after cholecystectomy. Columns denote areas of curves in controls and after cholecystectomy.

controls but was without influence on their level in patients after cholecystectomy. Statistical evaluation by means of the $t$ test showed that the difference between both groups was, in spite of a large variability of values, significant within the first hour after the administration of oil $(0.05>P>0.01)$. The area of bile acid curves was also significantly reduced after cholecystectomy $(0.05>P>0.01)$. In spite of the substantial difference of intestinal bile acid concentration between both groups, no significant decrease $(P>0.05)$ of alimentary lipaemia after cholecystectomy was observed (Fig. 2).

Two further experiments were designed to see whether bile supplements or synthetic emulsifying agents may enhance the fat absorption after cholecystectomy.

EXPERIMENT 3 Six patients after cholecystectomy were given intraduodenally $50 \mathrm{ml}$. olive oil. The experiment was repeated within five to seven days and with the addition of 2-5 g. of dried ox bile. The bile supplement caused a slight but insignificant increase of alimentary lipaemia in five patients.

EXPERIMENT 4 The previously described experiment was repeated with the addition of Tween 80 (Bayer, Leverkusen) instead of ox bile. The experiments were carried out in six patients after cholecystectomy and in five controls.
The addition of Tween 80 resulted in a marked increase of alimentary lipaemia in patients after cholecystectomy (Fig. 3). The difference between the first and the repeated experiment was statistically significant (Wilcoxon's non-parametric test described by Siegel (1956) within the first hour following the fat meal $(0.05>P>0.01)$. It is probable that in a larger group of patients a significance even within other time intervals could be proved. In controls after the addition of Tween 80 a variable effect was seen with an increase in the lipaemia in two subjects, a decrease in two, and no change in one.
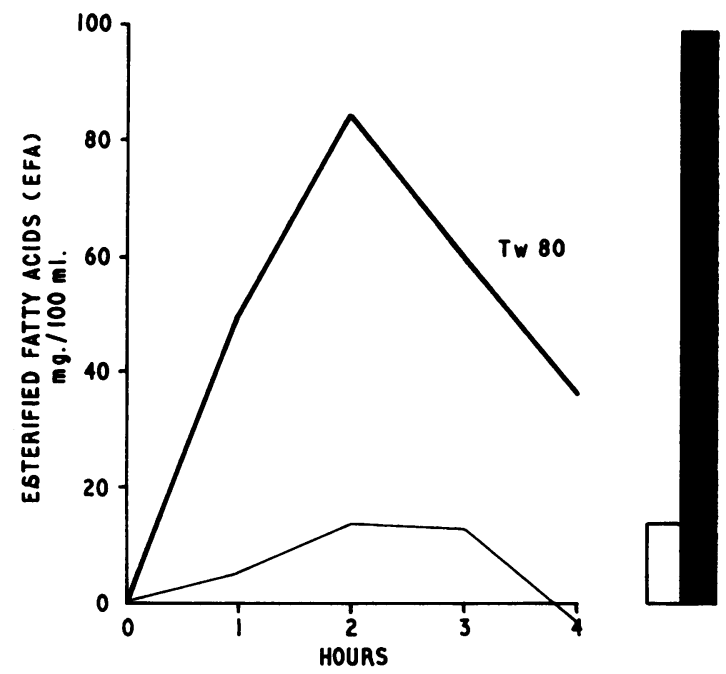

FIG. 3. The influence of Tween 80 on the absorption of fat following the intraduodenal administration of $50 \mathrm{ml}$. olive oil in six patients after cholecystectomy. The fine line is the mean curve without Tween 80 in six patients and the thick line is the mean curve after addition of $2 \mathrm{~g}$. of Tween 80 in the six patients. Columns denote the corresponding areas of curves without the emulgator (white) and after addition of Tween 80 (black).

EXPERIMENT 5 To complete the investigation fat balances on a standard diet were performed in 10 controls and eight patients after cholecystectomy. The diet was composed of protein $95 \mathrm{~g}$., carbohydrates $360 \mathrm{~g}$., fat $85 \mathrm{~g}$. (olive oil or butter), a total of 2,540 calories. The faeces were collected from the third to the eighth day and the faecal fat was estimated according to the method of Van de Kamer (1949).

No differences between the groups were observed (Fig. 4). However, in patients after cholecystectomy a larger variation in faecal fat content was found.

\section{DISCUSSION}

The results of our experiments suggest that the evacuation of the gall bladder is not essential for 


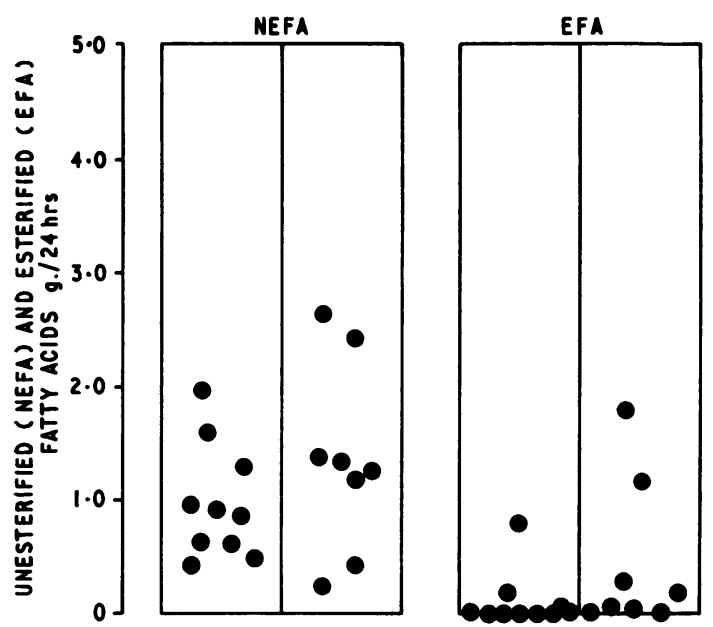

FIG. 4. The faecal fat content during ingestion of a standard diet containing $85 \mathrm{~g}$. fat $/ 24 \mathrm{hr}$.

the rate of absorption and digestibility of olive oil and butter in man. This conclusion is supported by two further observations. Redetzki and Gronow (1955) reported that the withdrawal of duodenal contents after evacuation of the gall bladder (by means of $\mathrm{MgSO}_{4}$ ) did not influence the absorption of subsequently applied olive oil intraduodenally. Similar results were reached in our preliminary unpublished experiments performed in dogs with jejunal fistula before and after cholecystectomy.

Opinions vary as to the effect of ox bile on fat absorption. Our experiments with dried ox bile are in agreement with an earlier observation in bile fistula dogs (Heersma and Annegers, 1948). Later on, however, it was shown that the addition of dried ox bile $(1.5$ to $2.5 \%)$ enhances the absorption of fat from ileal loops in dogs (Annegers, 1957).

In evaluating the effect of bile on fat absorption its composition must be considered. The analysis of the bile used by us showed that the main constituent was cholic acid; more than $50 \%$ of the bile acids were unconjugated. According to Dawson and Isselbacher (1960) the unconjugated bile acids have an unfavourable influence on the uptake of palmitate in vitro.

The favourable influence of Tween 80 on fat absorption is emphasized by several authors (Jones, Culver, and Drummey, 1948; Becker, Meyer, and Necheles, 1950; Brien, Turner, Watson, and Geddes, 1952; Krondl and Bohdalov́a, 1959) but denied by others (Heersma and Annegers, 1948; Demole, and Arpin-Morand, 1952; Tidwell and Nagler, 1953; Holt, Tidwell, Kirk, Cross, and Neale, 1935).

The substantial increase of alimentary lipaemia with Tween 80 after cholecystectomy was to a certain extent in disagreement with the rest of our results.
The explanation of this phenomenon is difficult because of the various effects of Tween 80 on fat metabolism. These effects include: emulsification of fat; inhibition of pancreatic lipase removed by bile salts (Minard, 1953; Krondl, 1961d); depression of palmitate uptake by the everted intestine of rat; and enhancement of mucosal esterification of the absorbed fatty acid (Dawson and Isselbacher, 1960).

In the elucidation of our results the following possibilities should be considered. In the absence of high concentrations of bile acids, or some other factor in the bile, Tween 80 may provoke some physico-chemical changes in the absorbed fat which in turn could affect (retard) its removal from the blood. In the experiments with cream and olive oil some differences in serum turbidity after cholecystectomy were observed but unfortunately could not be evaluated because of the broad variation of values. For better understanding of the effect of Tween 80 on fat absorption further investigations are required.

From our own and other quoted results it may be concluded that the fat intolerance observed in some patients after cholecystectomy is probably not caused by malabsorption, but two further factors, alone or in combination, impaired digestion and acquired intolerance (hypersensitivity), to certain fats or their constituents should be considered. Further results (to be published) suggest the first factor as a possibility.

\section{SUMMARY AND CONCLUSIONS}

The role of the gall bladder in fat absorption was investigated in patients after cholecystectomy and in controls. After ingestion of cream $(0 \cdot 85 \mathrm{~g}$. fat $/ \mathrm{kg}$. body weight) or intraduodenal application of olive oil $(0 \cdot 86 \mathrm{fat} / \mathrm{kg}$. body weight) no significant differences in alimentary lipaemia between the two groups were established. The addition of 2.5 dried ox bile to olive oil failed to enhance significantly the alimentary lipaemia in patients after cholecystectomy. However, the administration of $2.0 \mathrm{~g}$. Tween 80 caused a significant increase of alimentary lipaemia in these patients. No difference in faecal elimination of fat between patients after cholecystectomy and controls were found.

It may be assumed that removal of the gall bladder does not influence the absorption of butter fat and olive oil, and that the evacuation of the gall bladder is not essential for the absorption of these types of fat in man.

\section{REFERENCES}

Annegers, J. H. (1957). Absorption of lipid and cholate from ileal loops in unanesthetized dogs. Amer. J. Physiol., 191, 75-80.

Becker, G. H., Meyer, J., and Necheles, H. (1950). Fat absorption in young and old age. Gastroenterology, 14, 80-92. 
Brien, F. S., Turner, D. A., Watson, E. M., and Geddes, J. H. (1952) A study of carbohydrate and fat absorption from the norma and diseased intestine in man. II. Changes from the serum lipids in man after the ingestion of butterfat with and without Tween 80 (Sorlate). Ibid., 20, 294-297.

Bučko, A., and Dvorský, A. (1957). Zur Frage der Stoffwechselstörungen nach Cholezystektomie. Dtsch. $Z$. Verdau-V. Stoffwechselkr., 17, 179-186.

Cottet, J. (1939). Les sels biliaires en bilogie et en therapeutique. J. belg. Gastro-ent., 7, 165-190.

Dawson, A. M., and Isselbacher, K. J. (1960). Studies on lipid metabolism in the small intestine with observation on the role of bile salts. J. clin. Invest., 39, 730-740.

Demole, M., and Arpin-Morand, M. (1952). L'utilisation de la réaction au bleu de Nil comme moyen d'appréciation rapide de la teneur en graisses des matières fécales. Gastroenterologia (Basel), 78, 249-254.

Fedor, E. J., and Fisher, B. (1960). The use of radioactive iodine labeled triolein in the evaluation of fat absorption following cholecystectomy. Surg. Gynec. Obstet., 111, 206-210.

Ginter, E., Bobek, P., Blažek, Z., and Cerveň, J. (1963). The effect of experimental cholecystectomy on the resorption of $I^{131}$-labelled fats in cats. Gastroenterologia (Basel), 99, 301-310.

Heersma, J. R., and Annegers, J. H. (1948). Effect of cholecystectomy on fecal fat excretion in dogs. Proc. Soc. exp. Biol. (N.Y.). 69 , 140-141.

Holt, L. E. Jr., Tidwell, H. C., Kirk, C. M., Cross, D. M., and Neale, S. (1935). Studies in fat metabolism. I. Fat absorption in normal infants. J. Pediat., 6, 427-480.

Ivy, A. C. (1953). Physiology of the liver, bile and gall bladder. In Portis S. A.: Diseases of the Digestive System, 3rd ed., pp. 128-147. Lea and Febiger, Philadelphia.

Jones, C. M., Culver, P. J., Drummey, G. D., and Ryan, A. E. (1948). Modification of fat absorption in the digestive tract by the use of an emulsifying agent. Ann. intern. Med., 29, 1-10.

Kamer, van de J. H., Huinink, H. ten Bokkel, and Weyers, H. A. (1949). Rapid method for determination of fat in feces. J. biol. Chem., 177, 347-355.

Krondi, A., and Bohdalová, V. (1959). Použiti syntetickych emulgátoru $\mathrm{v}$ lex́ç steatorrhey. (The use of synthetic emulgators in therapy of steatorrhoea.) Cs. Gastroent. Výż., 13, 36.
Krondl, Michalec, C., Vavřinková, H., and Vokáč, V. (1961a). Vyznam koncentrace žlučových kyselin pro přeměnu tukủ. I. Stěpeni a emulgace tuků u clověka. (The role of concentration of bile acids in fat metabolism. I. The digestion and emulgation of fat in man.) Ibid., 15, 31-38.

$\ldots$ - - and Placer, Z. (1961b). Vyznam koncentrace żlucovych kyselin pro přemènu tuku . 2. Tráveni tuku s rủznym bodem tani. (The role of concentration of bile acids in fat metabolism. 2. Digestion of two lipids with different melting points.) Ibid., $15,112-116$

__ _ , and Michalec, C. (1961)c. Význam koncentrace žluxových kyselin pro přeměnu tuků. 3. Vstřebávání tuků u clověka. (The role of concentration of bile acids in fat metabolism. 3. The fat absorption in man.) Ibid., 15, 282-289.

_-_, and Vavŕinková, H. (1961d). Význam koncentrace žlučových kyselin pro přemexnu tuků. 4. Vliv hovězi žluče a Tweenu 80 na vstřebávání tuků u člověka. (The role of concentration of bile acids in fat metabolism. 4. The influence of ox bile and Tween 80 on the fat absorption in man.) Ibid., 15, 371-377.

- - - (1961e). Význam koncentrace żlučových kyselin pro přemènu tuků. 5. Vylučování tuků u člověka. 6. Shrnuti a závěry ze sděleni $1-5$. (The role of concentration of bile acids in fat metabolism. 5. The elimination of fat in man. 6. Summary and conclusions.) Ibid., 15, 378-381.

Minard, F. N. (1953). The inhibition of the action of pancreatic lipase by esters of polyoxyethylene sorbitan. J. biol. Chem., 200. 657-660.

Redetzki, H., and Gronow, R. T. (1955). Untersuchungen über die Fettresorption und die alimentare lipamie nach Fettbelastung. Klin. Wschr., 33, 701-705.

Schöndube, W. (1956). Die Erkrankungen der Gallenwege. Enke, Stuttgart.

Siegel, S. (1956). Nonparametric statistics: for the behavioural sciences. pp. 116-127. McGraw-Hill, New York.

Stern, I., and Shapiro, B. (1953). A rapid and simple method for the determination of esterified fatty acids and for total fatty acids in blood. J. clin. Path., 6, 158-160.

Tidwell, H. C., and Nagler, M. E. (1953). Effect of emulsifiers on fat absorption in the normal young adult. Gastroenteralogy, 23, 470-476.

\section{CORRECTION}

It is regretted that a phrase was omitted in the last sentence of the last paragraph in column 1 on page 410 of the paper 'Gastric ulcers, blood groups, and acid secretion' by H. Daintree Johnson, A. H. G. Love, N. C. Rogers, and A. P. Wyatt (Gut, 5, 402-411). The sentence should read: 'Overwhelming of mucus secretion by an excessively prolonged rather than an excessively powerful acid-peptic attack may be all-important in these cases.' 